\title{
Do a threatened native amphibian and its invasive congener differ in response to human alteration of the landscape?
}

\author{
Antonia D'Amore • Valentine Hemingway • \\ Kerstin Wasson
}

Published online: 27 March 2009

(C) Springer Science+Business Media B.V. 2009

\section{Erratum to: Biol Invasions \\ DOI 10.1007/s10530-009-9438-z}

In the original publication under the Methods section, the last line of the first paragraph for the subheading "Statistical analyses" currently reads " $P>.05$ and $<.75$ " was incorrect.

The correct data is " $P>.05$ and $<.075$ ". doi:10.1007/s10530-009-9438-z.

A. D’Amore $(\bowtie) \cdot K$. Wasson Elkhorn Slough National Estuarine Research Reserve, Watsonville, CA 95076, USA e-mail: nina@elkhornslough.org; damore@biology.ucsc.edu

V. Hemingway $\cdot$ K. Wasson Ecology and Evolutionary Biology, University of California, Santa Cruz, CA 95064, USA 